\title{
A Study of Citizen Satisfaction for e-Governance Initiative SETU in Maharashtra (INDIA)
}

\author{
Prajakta N. Warale \\ SSMS'S IMR \\ SP Pune University \\ Pune (Maharashtra)
}

\author{
Hemalatha Diwakar \\ Ex-state Bank of India IT Chair Professor, \\ National Institute of Bank Management, \\ Pune (Maharashtra)
}

\begin{abstract}
Every state in India is introducing citizen centric e-governance initiatives with the objective of providing government services [1] with greater transparency (hence corrupt free), accessibility, efficiency and high level of service quality in an integrated manner. Being a densely populated country, the implementations are challenging and time consuming [2]; hence a time-to-time evaluation of these systems, while in progress will aid in making mid-course corrections and improvements to attain their objectives in totality. "SETU" a very important e-governance initiative of Maharashtra state provides more than thirty vital services with a target of twenty more additional services. This paper describes the first of its kind study on SETU that has been in existence for more than a decade and spans the entire state. The key outcomes of the study revealed that the citizens are marginally satisfied with service quality and that the government has to reengineer its current processes and introduce latest technologies in order to accomplish its objectives of accessibility, efficiency and service levels.
\end{abstract}

\section{Keywords}

E-governance, Maharashtra, India, service quality, citizen satisfaction,

\section{INTRODUCTION}

The tremendous growth in ICT has paved a way for all the countries over the world to provide e- government services to their citizens [3]. India being no exception, all the states in India is into introducing e-governance projects for providing various citizens centric services [4]. One of the most literate industrialized states with a population density of 950 per square mile (second largest populated state) Maharashtra, has come up with a very large e-governance initiative called 'SETU ' that spans the entire state.

Department of Information Technology (DIT) and Government of Maharashtra (GoM) initiated SETU in 2001 with a single window citizen service centers called SETU Suvidha Centers (SSC) providing various services to the citizens [5]. Some of the key features of SETU are:

- Spread across all 36 districts and covers 333 sub districts in Maharashtra.

- On an average 30 services/certificates are offered through their centers; Nationality certificate, caste certificate, non-creamy layer certificate, income certificate, rahivasi dakhala, different certificates required by freedom fighter's relatives, various certificates required by farmers and so on [6].

SETU is implemented and run on BOT (Built operate and transfer) basis that allows vendors to have free hand to develop their own software for SETU [5]. Hence, every district or even sub district may have different software, the only requirement being strict adherence to the standard inputs (fields in application) and outputs (certificates format) set by GoM. Due to the heterogeneity in the software, the system remains decentralized till now. All SSCs are standalone delivery centers. It is interesting to note that the Government has set 'providing services in an integrated manner' $^{6}$ [6] as one of its main objectives which is still a distant dream!.

Due to heterogeneity, decentralized structure, wide geographical spread, its enormity in scale, it is critical to evaluate whether the initiative SETU has accomplished the objectives such as

- $\quad$ Service quality

- Citizen satisfaction

- Easy availability, timeliness

- Transparency (which directly implies corruption free system)

- $\quad$ Service delivery in an integrated manner.

It is worthwhile to mention that though the system has been in existence for more than a decade, a critical study of the system was never carried out. This forms the main theme of the paper. In the next section, we present the current working of the system.

\section{CURRENT WORKING OF SYSTEM SETU}

The time sequence diagram of application processing for certificates in the current system SETU is presented in figure 1. It is to be noted that the same operational flow is followed for the past fourteen years.

- Citizens approach SETU center with service request They submit application forms.

- Every application undergoes initial scrutiny for accuracy.

- On submission, the application is stamped and is accepted with enclosures (proofs) and affidavit, for further scrutiny, done later.

- Fees are collected from applicant and token with expected date of delivery of certificate is handed over to citizen.

- Lead time set by the government for certificate delivery is generally 7 days for most of the services. Citizens are informed about the status of application only after 7 days when they come personally to the same SSC as the current system doesn't offer any status tracking facility [7]. 
- Typically, certificates are delivered to citizens within a time span of 7 to 30 days.

Only when the citizen visits the same SSC where he/she has submitted the forms, he will know the status of his application that :

- Either application is successfully processed; hence certificate is ready or

- It was faulty or incomplete with missing enclosures.

The current situation leads to delays, frustrations, and uncertainty to citizens.

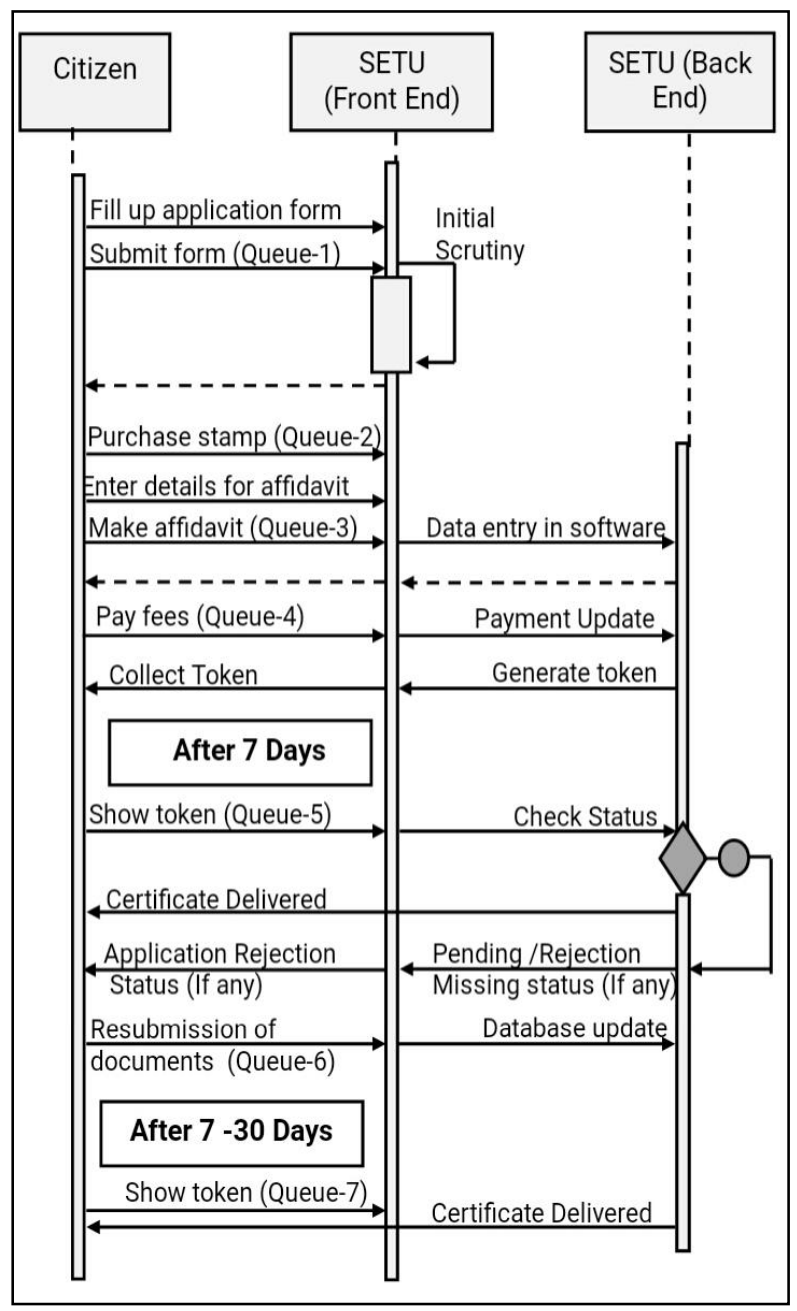

Figure 1: Time Sequence Diagram for certificate processing at SETU

It may be noted that though SETU started in 2001, it did not scale up to the expectations. Only thirty types of services are delivered to citizens while the original proposal aimed at more than fifty services.

As stated earlier since no study has been conducted to find out whether the current system has accomplished the objectives in totality, a pilot study in Pune district was carried out as a first step. It brought out the pitfalls in the current system related to service delivery, staff cooperation, transparency, timeliness and infrastructure related issues. Therefore, a detailed study using a descriptive research based method along with multistage sampling was carried out in depth. In the next section the objective and research methodology followed are presented.

\section{OBJECTIVES \& RESEARCH METHODOLOGY}

\subsection{Objectives}

1. The primary objective of research was to study and analyze satisfaction of citizens towards e-governance initiative SETU in selected districts of Maharashtra.

2. Secondary objective is to study the accomplishment of the aim and objectives of SETU set by the GoM[6].

The pilot study identified eight parameters viz., timeliness of service, accuracy of service, cooperation from SETU staff, Ease of use of procedure, promptness in service delivery, privacy of documents, cost of the service and transparency as the major contributing factors for service delivery [8]. Accordingly, suitable questions were incorporated in the questionnaire to evaluate SETU in terms of these parameters. Next section explains the conceptual framework for citizen satisfaction.

\subsection{Citizen Satisfaction-A conceptual framework}

In [8] service quality is defined as a "function of the differences between expectation and performance along the quality dimensions". Service quality and citizens' satisfaction are very closely related i.e., Citizens' satisfaction can be ensured by offering better quality of services [9]. Figure 2 explains a conceptual framework for citizen satisfaction.

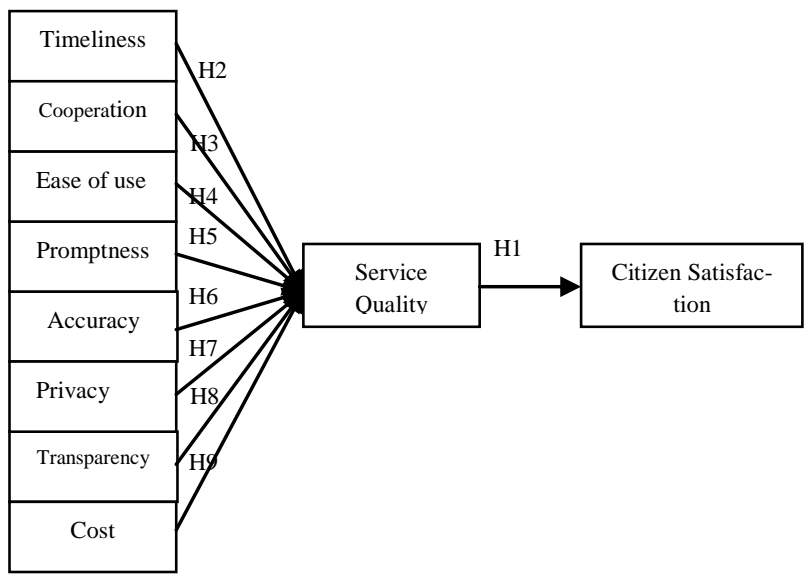

Figure 2: Conceptual framework

A brief description of service quality parameters are given below:-

- Timeliness: refers to the number of days required to deliver certificate (set by the government) against the number of visits made by a citizen to get the certificate in reality.

- Cooperation: means assistance or help provided by SETU operators.

- Ease of use: Ease of use refers to simplicity of procedure in availing of the certificate.

- Promptness: means zero or acceptable minimum waiting time for citizen at the counters in SSCs.

- Accuracy: Accuracy refers to correctness of the certificates delivered.

- Privacy:Privacy refers to protecting the confidentiality of the documents/proof submitted by citizen.

- Service Cost: Fees/charged for procuring the certificate.

- Transparency: Clarity and visibility of the procedure in the entire application process work flow. This also 
results in knowing the status of applications at any given point in time.

\subsection{Hypotheses:}

\subsubsection{Primary Hypothesis:}

There is significant positive relationship between service quality and citizens' satisfaction for SETU project.

H0: There is no significant positive relationship between service quality and citizens' satisfaction.

H1: There is significant positive relationship between service quality and citizens' satisfaction

As service quality comprises of eight parameters, primary hypothesis further alienated into eight hypotheses.

\subsubsection{Secondary Hypotheses:}

H2: There is significant positive relationship between timeliness of service and citizens' satisfaction.

H3: There is significant positive relationship between cooperation of Staff and citizens' satisfaction.

H4: There is significant positive relationship between Ease of use of procedure and citizens' satisfaction.

H5: There is significant positive relationship between promptness in service delivery and citizens' satisfaction.

H6: There is significant positive relationship between accuracy of service and citizens' satisfaction.

H7: There is significant positive relationship between privacy of documents and citizens' satisfaction.

H8: There is significant positive relationship between cost of the service offered and citizens' satisfaction.

H9: There is significant positive relationship between transparency and citizens' satisfaction.

\subsection{Research Design:}

\subsubsection{Sampling Method:}

A descriptive research method is used for the study. It includes surveys, fact-finding enquiries of different kinds, gathering data that describe events and data collection. Multistage Sampling method is used because selection of sample involved several stages viz., district, sub district and at SSC [10].The selection of the first two stages are based on population density using census 2011 data [11]. At first stage, three districts from Maharashtra were selected namely Pune, Sangli and Satara. At second stage, three Tehsils /sub districts were selected from the already chosen districts in a similar way. At third stage, i.e., selection of SETU centers, viz., SSCs. was done randomly. Morgan table was used for sample selection. A sample of 977 respondents was selected in total, from all three districts. Table 1 shows the distribution of sample.

Table 1 Sample Sizes

\begin{tabular}{|c|c|c|c|}
\hline District & Sub-District & Sample size & $\begin{array}{c}\text { Total sam- } \\
\text { ple size per } \\
\text { district }\end{array}$ \\
\hline \multirow{3}{*}{ Pune } & Haveli & 138 & \multirow{2}{*}{338} \\
\cline { 2 - 3 } & Baramati & 100 & \\
\cline { 2 - 3 } & Daund & 110 & \\
\hline Satara & Satara & 116 & 335 \\
\hline
\end{tabular}

\begin{tabular}{|c|c|c|c|}
\hline & Karad & 110 & \\
\hline & Patan & 109 & \multirow{4}{*}{304} \\
\hline \multirow{3}{*}{ Sangli } & Miraj & 101 & \\
\hline & Vita & 103 & \\
\hline & Tasgaon & 100 & \\
\hline & Total & 977 & 977 \\
\hline
\end{tabular}

3.4.2 Data Collection

Primary data was collected through two well-structured questionnaires.

Questionnaire I was designed for citizens. It consists of twenty five questions.

- Thirteen questions were related to service quality parameters viz., timeliness, cost, transparency, ease of service delivery, privacy, cooperation of staff, number of visits to SETU center, number of days required to get the certificate etc. Eight questions out of these thirteen, used 5 point Likert scale starting with 1 as "highly dissatisfied", 2 as "dissatisfied" 3 as "neither satisfied nor dissatisfied", 4 as "satisfied" and 5 as "highly dissatisfied".

- $\quad$ Five questions were used for gathering basic information of citizens like name, education age etc.

- The remaining questions were used to collect information on overall service delivery mechanism, complaints if any etc.

Questionnaire II was designed for service provider \& IT infrastructure, with thirty-seven questions in total.

- Fifteen questions were used to collect basic information about SSC and the employees /operators working there.

- Ten questions were used to collect data about IT infrastructure deployed in center.

- Remaining questions were about service delivery, training of employees, e-enablement of services, audits, technology used, disaster recovery, business continuity planning etc.

Secondary data was collected by visiting various national, state and district level governments' website, books, research papers on e-governance, e-governance policy, internal documentation of SETU, case studies and $\mathrm{PhD}$ thesis etc.

After data collection reliability of data was tested.

\subsubsection{Statistical tools used:}

Statistical package SPSS 20.0 was used to perform descriptive analysis, chi square analysis, and factor analysis on the data.

\subsubsection{Reliability analysis}

Reliability means consistency. It is the degree to which an instrument will give similar results for the same individuals at different times. Reliability can take on values of 0 to 1.0 inclusive. [10]

For reliability analysis, Chronbach's Alpha method was used.

Table 2: Reliability analysis

\begin{tabular}{|c|c|c|c|}
\hline District & Sample Size & $\begin{array}{l}\text { No of } \\
\text { Items }\end{array}$ & Chronbach's Alpha \\
\hline Pune & 338 & 25 & 0.952 \\
\hline Sangli & 304 & 25 & 0.880 \\
\hline Satara & 335 & 25 & 0.906 \\
\hline
\end{tabular}

(Source: Data Analysis performed with IBM SPSS 20.0)

Since value of alpha is greater than 0.70 , the sample is said to be reliable. In the next section data analysis is carried out. 


\section{DATA ANALYSIS}

\subsection{Descriptive statistics:}

Table 3.0 shows $74.8 \%$ of male visitors came to avail services through SETU whereas female visitors are $25.2 \%$.

- Age data shows that range of 18 to 25 has $42.2 \%$ respondents. This age group requires certificates nationality, domicile, caste, non-creamy layer, income for the purpose of admission.

- With respect to education it was found that $47.1 \%$ respondents are HSC \& graduates, $22 \%$ respondents are below 10th, approx. $19.4 \%$ respondents are post graduates. Respondents with graduate and under graduate degree are more because they require different certificate like caste, nationality/domicile, or creamy layer etc. to get government scholarship or concession in fees in colleges.

Following table provides descriptive statistics for the sets of variable in the study.

Table3: Demographic characteristics of citizens:

\begin{tabular}{|c|c|c|c|c|}
\hline $\begin{array}{l}\text { Sr. } \\
\text { No. }\end{array}$ & $\begin{array}{l}\text { Variable } \\
\text { Name }\end{array}$ & Categories & $\begin{array}{c}\text { Fre- } \\
\text { quency }\end{array}$ & $\begin{array}{c}\text { Per- } \\
\text { centage }\end{array}$ \\
\hline \multirow[t]{2}{*}{1} & \multirow[t]{2}{*}{ Gender } & Male & 731 & 74.8 \\
\hline & & Female & 246 & 25.2 \\
\hline \multirow[t]{5}{*}{2} & \multirow{5}{*}{$\begin{array}{l}\text { Age } \\
\text { group }\end{array}$} & $18-25$ & 411 & 42.2 \\
\hline & & $26-35$ & 236 & 24.2 \\
\hline & & $36-45$ & 183 & 18.7 \\
\hline & & $46-55$ & 84 & 8.6 \\
\hline & & More than 55 & 63 & 6.4 \\
\hline \multirow[t]{4}{*}{3} & \multirow{4}{*}{$\begin{array}{l}\text { Educa- } \\
\text { tion }\end{array}$} & Up to $10^{\text {th }}$ & 211 & 21.59 \\
\hline & & $\begin{array}{c}\text { HSC \& Grad- } \\
\text { uation }\end{array}$ & 460 & 47.08 \\
\hline & & $\begin{array}{c}\text { Post- } \\
\text { graduation }\end{array}$ & 190 & 19.4 \\
\hline & & $\begin{array}{l}\text { Don't know } \\
\text { read write }\end{array}$ & 116 & 11.9 \\
\hline \multirow[t]{6}{*}{4} & \multirow{6}{*}{$\begin{array}{l}\text { Distance } \\
\text { from } \\
\text { home }\end{array}$} & $0-5 \mathrm{~km}$ & 221 & 22.6 \\
\hline & & $6-10 \mathrm{~km}$ & 353 & 36.1 \\
\hline & & $11-20 \mathrm{~km}$ & 212 & 21.7 \\
\hline & & $21-30 \mathrm{~km}$ & 104 & 10.6 \\
\hline & & $31-40 \mathrm{~km}$ & 67 & 6.9 \\
\hline & & $\begin{array}{c}\text { More than } 40 \\
\text { km }\end{array}$ & 20 & 2.0 \\
\hline
\end{tabular}

(Source: Primary Data from Questionnaire 1)

- The age and education information presented here is used later to find out whether any meaningful relationship exists between them and overall citizen satisfaction; and the same is presented in section 4.3.

- $36 \%$ respondents' stay at a distance of 6 to $10 \mathrm{~km}$ and $22.6 \%$ of the respondents stay within a distance of $5 \mathrm{~km}$, whereas remaining respondents stay at a distance between 21 to $40 \mathrm{kms}$. Hence, it can be said that SETU centers are situated at convenient locations from residences of citizens so that ease of reachability is achieved.

\subsection{Analysis of citizens' satisfaction using bar chart}

From the 977 data samples collected, the level of satisfaction on 5-point Likert scale for all quality parameters is presented as bar chart in figure3. Some of the noteworthy observations are:

- Citizens have reported that they do not get certificates on time. The reasons observed from the study are unavailability of signing authority, improper guidelines from SETU operators, higher rate of rejection of applications.

- An interesting fact emerged from the district level data: other than Pune, the other two districts reported much higher satisfaction level from citizens.

$\circ \quad$ Non-cooperation of staff has been observed as one of the major complaint from citizens' in Pune district as operators did not clarify queries to citizens' satisfaction. Note that there are no other available means for getting their doubts cleared.

- More Pune citizens felt the procedures are not simple or easy, as compared to the citizens of other two districts.

- It is also significant to note that while $62 \%$ respondents are satisfied with privacy factor, citizens have complained that their documents were kept openly on the table and many times applications and enclosures went missing.

- SSCs charge more fees than prescribed by the government. It has been noticed that many citizens take assistance from middlemen also (agents); They pay higher charges demanded by them due to the urgency in getting certificates such as non-creamy layer, income, nationality etc. for the purpose of admission and scholarship, which are time critical. (The government documents do not mention anything about agents). So while overall citizens seem to be happy but in actual scenario citizens have complained about more money being spent at centers to procure the certificates. Hence one of the main purposes of eradicating corruption by e-governance is completely unfulfilled as there is no transparency in the existing system and absence of inspection or audit by the government to find out these practices.

- Overall Citizen Satisfaction : The overall percentage of satisfied users with the offered services, its delivery mechanism and overall management at SSCs is $52.10 \%$ That is just above average.

- $\quad$ Percentage of respondents carrying neutral response is 23.34. This percentage which is sizable, could have easily decided whether the curent system is saisfactory or not at all satisfactory if they have chosen any other options than the neutral one. 


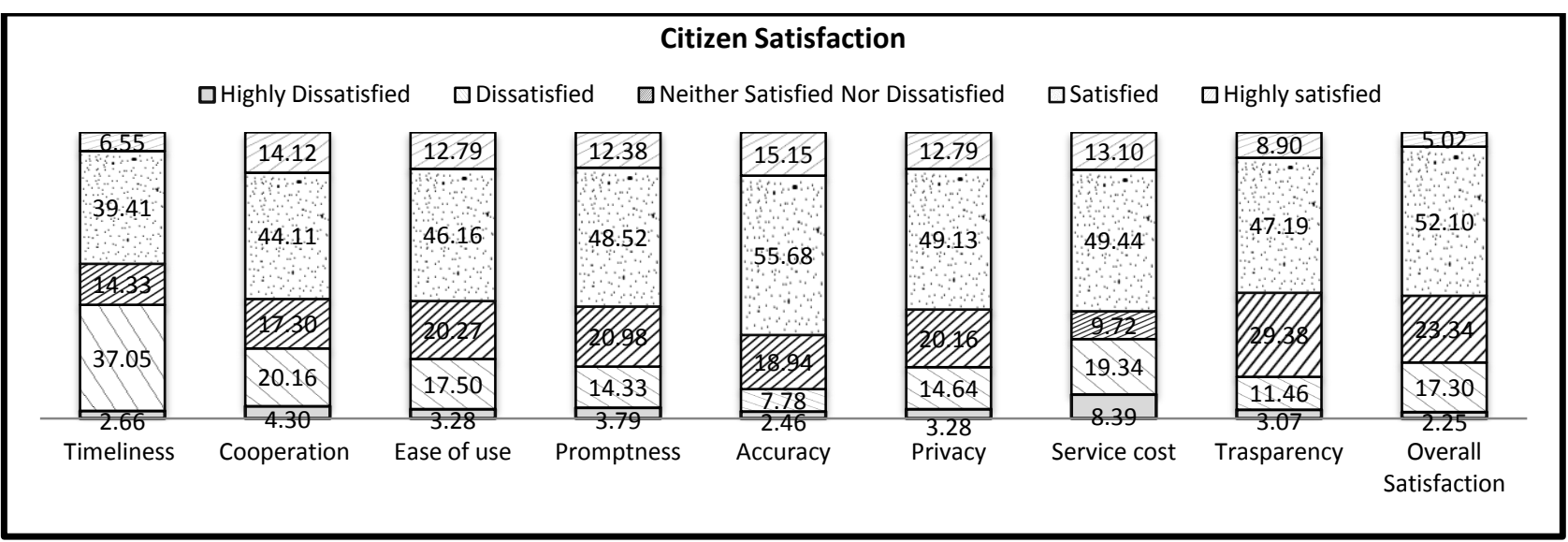

(Source: Primary Data from questionnaire I)

Figure 3: Level of citizen satisfaction

\subsection{Hypothesis Testing:}

\section{Cross tabulation with Chi square test}

Cross tabulation with Chi square test was used to measure relationship between all service quality parameters and citizen satisfaction at $5 \%$ level of significance. Timeliness, promptness, transparency, security, service cost, cooperation, Ease of use and accuracy are evaluated to measure citizen satisfaction. Table 4 shows for the entire eight constructs chi square value is 0.000 which is significant at $5 \%$ level. Hence, hypotheses $\mathrm{H} 2, \mathrm{H} 3, \mathrm{H} 4, \mathrm{H} 5, \mathrm{H} 6, \mathrm{H} 7, \mathrm{H} 8$ and $\mathrm{H} 9$ are proved to be significant. All eight hypotheses collectively confirm the significance of primary hypothesis. So we reject null hypothesis (H0) and accept alternate hypothesis (H1).

Please note that the values 1 to 5 are given to denote "highly unsatisfied, dissatisfied, neither satisfied nor satisfied, satisfied and highly satisfied" respectively in the SPSS.

Table 4: Cross tabulation Chi square values for citizen satisfaction parameters

\begin{tabular}{|l|l|l|l|l|l|}
\hline $\begin{array}{l}\text { S. } \\
\text { No }\end{array}$ & $\begin{array}{l}\text { Cross tabula- } \\
\text { tion Parame- } \\
\text { ters }\end{array}$ & $\begin{array}{l}\text { Pear- } \\
\text { son } \\
\text { Chi- } \\
\text { Square } \\
\text { Value }\end{array}$ & df & $\begin{array}{l}\text { Asy } \\
\mathrm{mp.S} \\
\text { ig }\end{array}$ & $\begin{array}{l}\text { Re- } \\
\text { mark }\end{array}$ \\
\hline 1 & $\begin{array}{l}\text { CS_Time*Ove } \\
\text { rall satisfaction }\end{array}$ & $\begin{array}{l}346.90 \\
6\end{array}$ & 16 & 0.000 & $\begin{array}{l}\mathrm{P} \\
\text { value } \\
<0.05\end{array}$ \\
\hline 2 & $\begin{array}{l}\text { CS_Accuracy* } \\
\text { Overall satis- } \\
\text { faction }\end{array}$ & $\begin{array}{l}365.16 \\
1\end{array}$ & 16 & 0.000 & $\begin{array}{l}\mathrm{P} \\
\text { value } \\
<0.05\end{array}$ \\
\hline 3 & $\begin{array}{l}\text { CS_Cooperatio } \\
\text { n*Overall } \\
\text { satisfaction }\end{array}$ & $\begin{array}{l}346.67 \\
0\end{array}$ & 16 & 0.000 & $\begin{array}{l}\mathrm{P} \\
\text { value } \\
<0.05\end{array}$ \\
\hline 4 & $\begin{array}{l}\text { CS_Ease of } \\
\text { use*Overall } \\
\text { satisfaction }\end{array}$ & $\begin{array}{l}371.78 \\
0\end{array}$ & 16 & 0.000 & $\begin{array}{l}\mathrm{P} \\
\text { value } \\
<0.05\end{array}$ \\
\hline 5 & $\begin{array}{l}\text { CS_Promptnes } \\
\text { s*Overall sat- } \\
\text { isfaction }\end{array}$ & $\begin{array}{l}336.71 \\
8\end{array}$ & 16 & 0.000 & $\begin{array}{l}\mathrm{P} \\
\text { value } \\
<0.05\end{array}$ \\
\hline 6 & $\begin{array}{l}\text { CS_Privacy*O } \\
\text { verall satisfac- } \\
\text { tion }\end{array}$ & $\begin{array}{l}354.93 \\
1\end{array}$ & 16 & 0.000 & $\begin{array}{l}\mathrm{P} \\
\text { value } \\
<0.05\end{array}$ \\
\hline 7 & $\begin{array}{l}\text { CS_Service } \\
\text { cost*Overall } \\
\text { satisfaction }\end{array}$ & $\begin{array}{l}305.74 \\
5\end{array}$ & 16 & 0.000 & $\begin{array}{l}\mathrm{P} \\
\text { value } \\
<0.05\end{array}$ \\
\hline
\end{tabular}

\begin{tabular}{|l|l|l|l|l|l|}
\hline 8 & $\begin{array}{l}\text { CS_Transpare } \\
\text { ncy*Overall } \\
\text { satisfaction }\end{array}$ & $\begin{array}{l}541.80 \\
2\end{array}$ & 16 & 0.000 & $\begin{array}{l}\text { P } \\
\text { value } \\
<0.05\end{array}$ \\
\hline
\end{tabular}

(Source: Data Analysis performed with IBM SPSS 20.0)

It is observed that the citizens are more satisfied with (1) accuracy and (2) cost of the service. At the same time, it has been observed that SETU operators charge more for the services than the government approved charges. But still the citizens are satisfied. An important fact to note is that there is a possibility of well stabilized and accepted "paying more" practice in the system that the citizens are used to.

Another independent interesting result emerged when an analysis using cross tabulation was done on age \& overall citizen satisfaction and education \& overall citizen satisfaction. The results are presented in table5.

Table 5: Cross tabulation of education and age with overall citizen satisfaction

\begin{tabular}{|l|l|l|l|l|l|}
\hline $\begin{array}{l}\text { Sr. } \\
\text { No }\end{array}$ & $\begin{array}{l}\text { Cross tabu- } \\
\text { lation Pa- } \\
\text { rameters }\end{array}$ & $\begin{array}{l}\text { Pear- } \\
\text { son } \\
\text { Chi- } \\
\text { Square } \\
\text { Value }\end{array}$ & df & $\begin{array}{l}\text { Asy } \\
\text { mp.S } \\
\text { ig }\end{array}$ & $\begin{array}{l}\text { Re- } \\
\text { mark }\end{array}$ \\
\hline 1 & $\begin{array}{l}\text { Education } \\
\text { *Overall } \\
\text { satisfaction }\end{array}$ & 30.453 & 12 & 0.002 & $\begin{array}{l}\mathrm{P} \\
\text { value } \\
<0.05\end{array}$ \\
\hline 2 & $\begin{array}{l}\text { Age } \\
\text { *Overall } \\
\text { satisfaction }\end{array}$ & 21.57 & 12 & 0.157 & $\begin{array}{l}\mathrm{P} \\
\text { value } \\
>0.05\end{array}$ \\
\hline
\end{tabular}

(Source: Data Analysis performed with IBM SPSS 20.0)

The $\mathrm{p}$ value for crosstab between education and overall satisfaction is less than 0.05 that shows that there is significant positive relationship between education and overall satisfaction, which indicates that there is appreciation for e-governance from the educated respondents. Cross tabulation with chi square between age and overall satisfaction shows $\mathrm{p}$ value more than 0.05 i.e. 0.157 . Thus the association is not significant. 


\subsection{Factor Analysis:}

Factor analysis is used when data contains many variables. It is used to reduce the number of variables. First step is to check whether the data are adequate to perform factor analysis. [12] Kaiser Meyer Olkin Test (KMO) and Bartlett's Test of sphericity shows value of 0.940 and 0.000 respectively, which indicated the significance.

\subsubsection{Total Variance Explained}

Extraction method used was principal component analysis. Table No.6 shows all the factors extractable from the analysis along with their Eigen values, the percent of variance attributable to each factor, and the cumulative variance of the factor.

Table 6: Total Variance Explained

\begin{tabular}{|c|c|c|c|c|c|c|}
\hline $\begin{array}{c}\text { Co } \\
\mathrm{mp}\end{array}$ & \multicolumn{2}{|c|}{ Initial Eigen Values } & \multicolumn{3}{c|}{$\begin{array}{c}\text { Extraction Sums of } \\
\text { Squared Loadings }\end{array}$} \\
\cline { 2 - 7 } $\begin{array}{c}\text { on } \\
\text { ent }\end{array}$ & Total & $\begin{array}{c}\text { \% of } \\
\text { Vari- } \\
\text { ance }\end{array}$ & $\begin{array}{c}\text { Cu- } \\
\text { mulat } \\
\text { ive \% }\end{array}$ & $\begin{array}{c}\text { To- } \\
\text { tal }\end{array}$ & $\begin{array}{c}\text { \% of } \\
\text { Vari- } \\
\text { ance }\end{array}$ & $\begin{array}{c}\text { Cumu- } \\
\text { lative } \\
\%\end{array}$ \\
\hline 1 & 3.962 & 44.02 & $\begin{array}{c}44.02 \\
6\end{array}$ & $\begin{array}{c}3.9 \\
6\end{array}$ & 44.02 & 44.026 \\
\hline 2 & 1.663 & 18.47 & $\begin{array}{c}62.50 \\
0\end{array}$ & $\begin{array}{c}1.6 \\
6\end{array}$ & 18.47 & 62.50 \\
\hline 3 & 1.541 & 17.12 & $\begin{array}{c}79.62 \\
6\end{array}$ & $\begin{array}{c}1.5 \\
4\end{array}$ & 17.12 & 79.63 \\
\hline 4 & 0.543 & 6.033 & $\begin{array}{c}85.65 \\
9\end{array}$ & & & \\
\hline 5 & .462 & 5.135 & $\begin{array}{c}90.79 \\
4\end{array}$ & & & \\
\hline 6 & .384 & 4.271 & $\begin{array}{c}95.06 \\
5\end{array}$ & & & \\
\hline 7 & .221 & 2.457 & $\begin{array}{c}97.52 \\
3\end{array}$ & & & \\
\hline 8 & .210 & 2.335 & $\begin{array}{c}99.85 \\
7\end{array}$ & & & \\
\hline 9 & .013 & 0.148 & 100 & & & \\
\hline
\end{tabular}

(Source: Data Analysis performed with IBM SPSS 20.0)

It is clear from the table that first component accounts for $44.02 \%$ of the variance, the second one $18.47 \%$ of the variance whereas $3^{\text {rd }}$ component accounts for $17.12 \%$ of the variance. The remaining factors 4 to 9 have Eigen value less than 1 and therefore explain less variance. It is significant to note that the cumulative percentage of variance explained by the first 3 factors is $79.63 \%$

\subsubsection{Component Matrix}

The component matrix indicates the correlation of each variable with each factor. The key to determining what the factors measure is the factor loadings [12].

Table 7: Rotated Component matrix

\begin{tabular}{|l|c|c|c|}
\hline \multirow{2}{*}{} & \multicolumn{3}{|c|}{ Component } \\
\cline { 2 - 4 } & 1 & 2 & 3 \\
\hline CS_Timeliness & .868 & & \\
\hline CS_Cooperation & .810 & & \\
\hline CS_Ease of Use & & .654 & \\
\hline CS_Promptness & .734 & .642 & \\
\hline CS_Accuracy & & .608 & .601 \\
\hline CS_Privacy & & & .725 \\
\hline CS_Service cost & & .761 & \\
\hline CS_Transperancy & .614 & .736 & \\
\hline overall CS & .678 & & \\
\hline
\end{tabular}

\begin{tabular}{|l|}
\hline Extraction Method: Principal Component Analysis. \\
Rotation Method: Varimax with Kaiser Normalization. \\
\hline a. Rotation converged in 6 iterations. \\
\hline
\end{tabular}

(Source: Data Analysis performed with IBM SPSS 20.0)

Factors can be grouped together as follows.

Factor 1- CS_Time, CS_Cooperation, CS_Promptness, Overall CS (Expectations of citizens)

Factor 2- CS_Service Cost, CS_Ease of use , S_Transperancy, (Quality of procedure)

Factor 3-CS_Accuracy,CS_Privacy (Quality of information) It is evident that components 'Timeliness' and 'cooperation' are heavily loaded on factor I; 'Service cost' is heavily loaded on factor 2 ; whereas component 'privacy' is heavily loaded on factor 3.It is worthy to note that similar results are found in figure 3 viz.,

- timeliness and cooperation are viewed as two critical factors for citizen satisfaction that need to be improved,

- Citizens are content with the 'service cost' which is heavily loaded on factor 2 .

In a nutshell we can say that timeliness, cooperation, service cost, accuracy are highly influential for citizen satisfaction. Thus all these four parameters must be improved further to ensure better citizen satisfaction.

\section{SUMMARY OF FINDINGS}

The purpose of this paper was to evaluate SETU with respect to service quality, citizen satisfaction and attainment of government's objectives. Our Descriptive study offers interesting insights into how service quality is realized by the citizens.

- $\quad$ Findings of the study as stated in section 4.2 based on the bar chart (figure 3 ) revealed that the citizens are satisfied overall with services, its delivery mechanism and management at setu centers viz.,SSCs .

- Results of chi square test presented in section 4.3 shows that $\mathrm{p}$ value for all variables is $<0.05$ thus the hypothesis $\mathrm{H} 1$ is accepted i.e. there is significant positive relationship between quality of services and citizens' satisfaction.

- The factor analysis presented in section 4.4 clearly indicates the conclusions arrived at are similar to the ones inferred using the bar chart of figure 3 .

- In addition, it was observed that there were citizens' complaints about improper guidance of staff, presence of agents, charging of high fees, misdirection, lack of communication between SSCs $\&$ citizens and nonintegrated service delivery. All these indicate that the objectives set by GOM for SETU are yet to be accomplished.

- $\quad$ IT audit \& inspection, disaster recovery and business continuity plan were found to be totally neglected grey areas.

Next section offers certain noteworthy suggestions for overall improvement of SETU for better performance.

\section{SUGGESTIONS}

Based on the analysis and findings presented in the previous sections the following actions are mandatory to rectify the shortcomings in the current SETU:- 
- Transparency: The transparency aspect of the system is not fully taken care of as citizens have to come to the same SSC to know the status of their application. Better transparency can be achieved by automating most of the business processes in the system such as automatic token generation, tracking, sending SMS alerts, etc., which will eradicate corruption.

- BPR: Business process reengineering is very critical. BPR[13] will help in work assignment to the employees dynamically based on needs and demands, queue monitoring and dynamically assigning various windows for application submission; certificate collection rejection based on the demands for various services along with more technology based automation.

- Waiting period to get the certificate in reality is much more than government set target. Hence, the BPR will help greatly to arrive at realistic deadlines. In addition, some of the main bottlenecks are signing authority's (tahsildar) non-availability and, same number of counters throughout the year; hence, appointment of a signing authority exclusively for this purpose and opening of multiple counters during peak time is mandatory to meet deadlines. This will help in reducing waiting period of citizens.

- Changes in technologies currently used both in the hardware and software level will be needed for streamlining the factors mentioned above.

- Audits are mandatory for better working of the system and this will do away with practices such as higher fees collection; dependence on agents or middle men from the system to provide more corruption free services.

- The very purpose of e-governance is to eradicate corruption. However as said earlier, the SETU service centers in some places are openly charging more fees for certificates than approved by the government. In addition, some of the citizens who were asked to fill the questionnaires turned out to be agents. It indicates clearly that because of agents' presence, preferential service might be possible. If surprise inspections are carried out, corrective measures can be taken.

- Collecting citizen feedback frequently and mechanisms such citizen grievance forums will help the government to provide more effective services.

- SETU is covering the entire state and has a bigger functional scope hence to rectify problems in service delivery it is necessary to offer services in an integrated manner. Further it is necessary to introduce online application and supporting documents submission, tracking the application online, online payment, using the unique aadhar number for application submission ( similar to social security number) which will pave a way for better e-governance and higher citizen satisfaction.

- The heterogeneous softwares currently being used are also a bottleneck, as they do not provide interoperability, web based tracking, online submissions and payments. Therefore, there is a need to rewrite or add on software to be deployed as SETU is vital for e-governance and has to proliferate to more services and cover all districts and sub districts.

\section{CONCLUSION}

E--governance initiatives are being rapidly introduced in many states of the country. These initiatives address a large population, have a wide geographical spread and need to evolve continuously to offer more and more services. Hence, it is vital for the government to constantly monitor the effectiveness of these services and make improvements as required. This paper presents a comprehensive approach to carry out evaluations of e-governance initiatives from quality of service and customer satisfaction perspective to help concerned agencies to rectify the current gaps in the system to achieve the ultimate aims and objectives.

This survey-based approach has been applied to study SETU - a well-known and important e-Governance initiative, which is being rolled out in the entire state of Maharashtra. This in-depth descriptive study covered all the three dimensions viz., Beneficiaries, Service Providers and Technology \& Business Processes with focus on "the service quality and citizen satisfaction". The descriptive study approach used SPSS to analyze survey responses. The findings and hence the corrective measures to improve the service quality are presented in this paper. As a next step, work related to issues such as "sufficiency of infrastructure", "latest technological advances versus the present technologies used in SETU implementations" and "service providers' competencies", with respect to objectives of the government is being carried out. The questionnaire II is extensively used for this purpose and analysis is carried out using SPSS [14]. Finally, all the above results will be used in analyzing the whole SETU system in totality to identify existing problems and gaps. Also corrective measures to rectify the same will also be worked out.

\section{REFERENCES}

[1] P.N.Gupta, (May 2008), e governance: A comprehensive framework, new century publication

[2] Bhatnagar S.C., (2004) "E-Government: From Vision to Implementation - A Practical Guide with Case Studies", SAGE Publications Pvt. Ltd., New Delhi,

[3] UN's e-government report prepared by UN's Department of economics and social affairs 2014.

[4] Sushil Kumar Singla, Himanshu Aggarwal(2012), Impact and Scope of e-Governance Initiatives in State of Punjab (INDIA),IJCA, Volume 44- No14, April 2012.

[5] State of e-governance in Maharashtra, Annual report published by DIT, GoM, 2014.

[6] www.indg.in/e-governance/e-governance-initiativesin-Maharashtra/

[7] SETU Detail tender document(District SETU),Court naka Thane, Maharashtra, India, Tender No: General/section-4/SETU,F-2,Date:14/8/2014

[8] Parasuraman, A., Zeithaml, V., Berry, L. L., "A Conceptual Model of Service Quality and Its Implication for Service Quality Research", Journal of Marketing, 49, Fall, 1985, p. 44 and Zeithaml, V. A., Berry, L. L., 
[9] Umesh Gunarathne W.H.D.P ,Relationship between Service Quality and Customer Satisfaction in Sri Lankan Hotel Industry, International Journal of Scientific and Research Publications, Volume 4, Issue 11, November 2014

[10] Donald Cooper, Pamela S.Schindler,J K Sharma, Business Research Methods,McGraw -Hill Edition 2012,p. 21-22,172-173 .

[11] www.censusindia.gov.in/2011cencus/population_enum eration
[12] Notes on Factor Analysis: Charles M. Friel Ph.D., Criminal Justice Center, Sam Houston State University, June 2015.

[13] Xenakis A and Macintosh A (2005)“Using Business Process Re-engineering (BPR) for the Effective Administration of Electronic Voting" The Electronic Journal of e-Government Volume 3 Issue 2, pp. 91-98,

[14] Prajakta warale, Hemalatha Diwakar(2015) "A critical study of SETU, an e-governance initiative of Maharashtra "- under preparation. 